\title{
Anion Ordering in Bichalcogenides
}

\author{
Martin Valldor \\ Physics of Correlated Matter, Max Planck Institute for Chemical Physics of Solids, Nöthnitzer Str. 40, \\ 01187 Dresden, Germany; martin.valldor@cpfs.mpg.de; Tel.: +49-351-4646-4424 \\ Academic Editors: Richard Dronskowski and Duncan H. Gregory \\ Received: 15 April 2016; Accepted: 19 July 2016; Published: 22 July 2016
}

\begin{abstract}
This review contains recent developments and new insights in the research on inorganic, crystalline compounds with two different chalcogenide ions (bichalcogenides). Anion ordering is used as a parameter to form structural dimensionalities as well as local- and global-electric polarities. The reason for the electric polarity is that, in the heterogeneous bichalcogenide lattice, the individual bond-lengths between cations and anions are different from those in a homogeneous anion lattice. It is also shown that heteroleptic tetrahedral and octahedral coordinations offer a multitude of new crystal fields and coordinations for involved cations. This coordination diversity in bichalcogenides seems to be one way to surpass electro-chemical redox potentials: three oxidation states of a single transition metal can be stabilized, e.g., $\mathrm{Ba}_{15} \mathrm{~V}_{12} \mathrm{~S}_{34} \mathrm{O}_{3}$. A new type of disproportionation, related to coordination, is presented and results from chemical pressure on the bichalcogenide lattices of (La,Ce) $\mathrm{CrS}_{2} \mathrm{O}$, transforming doubly $\left[\mathrm{CrS}_{3 / 3} \mathrm{~S}_{2 / 2} \mathrm{O}_{1 / 1}\right]^{3-}(5+1)$ into singly $\left[\mathrm{CrS}_{4 / 2} \mathrm{~S}_{2 / 3}\right]^{7 / 3-}(6+0)$ and $\left[\mathrm{CrS}_{4 / 3} \mathrm{O}_{2 / 1}\right]^{11 / 3-}(4+2)$ coordinations. Also, magnetic anisotropy is imposed by the anion ordering in $\mathrm{BaCoSO}$, where magnetic interactions via $\mathrm{S}$ or $\mathrm{O}$ occur along two different crystallographic directions. Further, the potential of the anion lattice is discussed as a parameter for future materials design.
\end{abstract}

Keywords: anion; chalcogenide; superstructure; heteroleptic coordination; crystal field; charge ordering; coordination disproportionation; magnetic anisotropy

\section{Introduction}

In solid-state inorganic chemistry, the anion lattice is usually mentioned as a matrix where the cations dwell. The latter, positively charged, ions are chiefly in the research focus because their valence electrons are responsible for physical properties, like magnetism, optic activity, and conductivity. As a result, the fundamental aspects of the potentially interesting anion lattice receives relatively little attention. In this review, the elements in main group 16, the chalcogenides, will be used to display the possibilities of the anion lattice and how its design is related to new chemical situations that eventually lead to desirable properties. Focus is placed on describing the ordering of two anions, so solid-solutions will be disregarded.

According to Hume-Rothery [1], if the size difference of two atoms/ions, composing a common lattice, is larger than $\sim 10 \%$, an ordered superstructure is formed rather than a solid solution. Hence, by considering the sizes of the two-fold negatively charged chalcogenide ions $\left(r\left(\mathrm{O}^{2-}\right)=1.26 \AA\right.$, $r\left(\mathrm{~S}^{2-}\right)=1.70 \AA, r\left(\mathrm{Se}^{2-}\right)=1.84 \AA$, and $r\left(\mathrm{Te}^{2-}\right)=2.07 \AA$ ) [2], anion ordering is most probable for sulfide-oxides, selenide-oxides, telluride-oxides, and perhaps telluride-sulfides. These chemical prerequisites are chosen in this review to keep the focus on the phenomenon (anion superstructures) instead of on its vast possibilities.

Below, causes and consequences of involving two chalcogenides into one crystal lattice are presented. Each case is briefly introduced and subsequently discussed on the basis of existing compounds. At the end of this review, further possibilities are given, but only with a few practical examples. 
So far, there are several known examples of bichalcogenides, but many of them were obtained by chance, often admitted in honesty by the discoverers themselves. By comparing existing compounds, this review aims to initiate an understanding in this research field.

\section{Causes and Consequences of Chalcogenide Ordering}

\subsection{Partial Anionic Substitution}

Despite a significant size difference between two anions, a stoichiometric composition of two anions might build up a common lattice with great similarities to that of an anion homogeneous one. For example, the ternary $\mathrm{La}_{2} \mathrm{SO}_{2}$ [3] is isostructural to the binary $\mathrm{La}_{2} \mathrm{O}_{3}$ [4], but exhibits an anion superstructure, i.e., $\mathrm{S}-\mathrm{O}$ ordering. Also, by replacing half of $\mathrm{O}^{2-}$ in $\mathrm{SrZnO}_{2}$ [5] by $\mathrm{S}^{2-}$ and at the same time substitute $\mathrm{Sr}^{2+}$ for $\mathrm{Ba}^{2+}$, the quaternary compound BaZnSO results [6]. As both compounds are structurally very similar, the latter sulfide oxide can be described as an anionic superstructure of the former. These kinds of anion substitutions are also expected to work both ways: for example, partly replacing $\mathrm{S}$ for $\mathrm{O}$ converts the anion lattice of $\mathrm{La}_{3} \mathrm{CuSiS}_{7}$ [7] (or $\mathrm{Ce}_{6} \mathrm{Al}_{10 / 3} \mathrm{~S}_{14}$ [8]) into that of $\mathrm{Ba}_{3} \mathrm{~V}_{2} \mathrm{~S}_{4} \mathrm{O}_{3}[9,10]$ and the latter is isostructural with the former, having even the same crystal symmetry. This means that there might be rational solubility of one chalcogenide in the matrix of another: These partial substitutions are possible if the anions in a candidate compound occupy two crystallographically unique sites, with preferably different environments.

\subsection{Structural Dimensionality}

The anion lattice dimensionality (D) is often inherited by the crystal structure as a whole. Decisive is the relative abundance of the two anions: the closer this ratio is to unity, the higher is the dimensionality. Hence, a 1:1 ration could constitute a 3-D lattice, a 2:1 ratio most likely a 2-D stacking, and a 6:1 probably leads to a 0-D structure e.g. a single anion surrounded by the other type of anion. For example, the sulfide-oxide $\mathrm{Eu}_{5} \mathrm{~V}_{3} \mathrm{~S}_{6} \mathrm{O}_{7}$ [11] contains a weaved net of $\mathrm{O}$ and $\mathrm{S}$ rows $(\mathrm{O} / \mathrm{S}=7 / 6 \approx 1)$ and is best described as a 3-D lattice. Two-dimensional layers of Se and $\mathrm{O}$ are found in $\mathrm{La}_{2} \mathrm{Fe}_{2} \mathrm{Se}_{2} \mathrm{O}_{3}$ [12] where the ratio $\mathrm{O} / \mathrm{Se}=1.5$. In $\mathrm{Bi}_{2} \mathrm{SO}_{2}$, stacked square layers of either $\mathrm{O}$ or $\mathrm{S}$ are observed [13] (Figure 1), with the ratio $\mathrm{O} / \mathrm{S}=2$. Quasi 1-D chains of Se ions penetrate the crystal structure of $\mathrm{Sr}_{2} \mathrm{Mn}_{2} \mathrm{SeO}_{4}$ [14], in correspondence to the composition O/Se $=4$. Single O ions are separated by $\mathrm{S}$ in $\mathrm{La}_{4} \mathrm{MnS}_{6} \mathrm{O}$ [15], which is a representative of a 0-D oxygen anionic order and the ratio $\mathrm{S} / \mathrm{O}=6$.

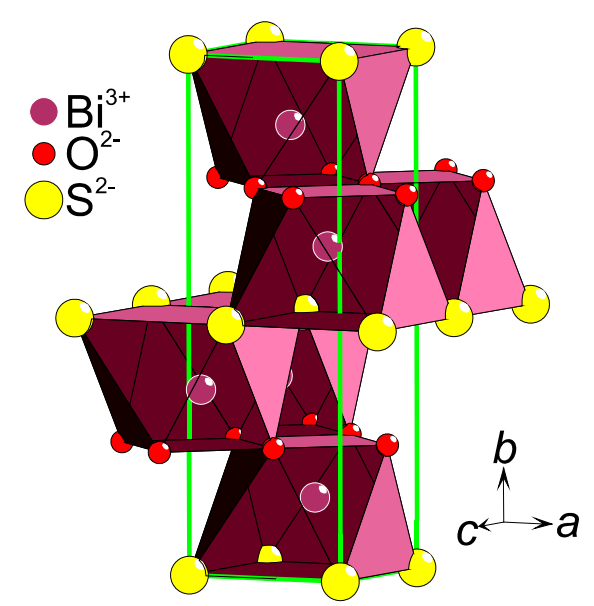

Figure 1. A part of the $\mathrm{Bi}_{2} \mathrm{SO}_{2}$ [13] crystal structure is shown as an example of a layered anion ordering. The heteroleptic coordination of $\mathrm{Bi}$ is emphasized with a polyhedron and the unit cell is drawn with green lines. 


\subsection{Charge Ordering}

By combining the concepts of anion superstructures with that of hard-soft-acid-base (HSAB), which is often used for ions in solutions [16], it becomes apparent that a charge ordering might accompany an anion ordering. This means that higher (lower) oxidation states would be found close to anions with higher (lower) electronegativity. Assuming that the hypothetical compound $\mathrm{TM}_{3} \mathrm{TeO}_{3}$ ( $T M=$ transition metal), with $T M^{2.67+}$ on average, exists and is charge ordered, it is most probable that $\mathrm{TM}^{2+}$ coordinates mainly to $\mathrm{Te}^{2-}$ and $T M^{3+}$ to $\mathrm{O}^{2-}$. In $\mathrm{Eu}_{5} \mathrm{~V}_{3} \mathrm{~S}_{6} \mathrm{O}_{7}$, a charge order is proposed due to semiconducting behavior although the mean valence of $\mathrm{V}$ is $+11 / 3(+3.67)[11]$ and corresponds to $1 \times \mathrm{V}^{3+}$ and $2 \times \mathrm{V}^{4+}$. As the crystal structure contains two $\mathrm{V}$ sites, it is possible to order the charges although the authors chose differently: both sites are in first approximation octahedrally coordinated, $\left[\mathrm{VS}_{4 / 2} \mathrm{O}_{2 / 1}\right]^{13 / 3-}$, with similar interatomic distances, making it difficult to see any preference for the charges. However, the sites have different multiplicities, according to the Wyckoff definition ( $4 f$ and $2 b$ ), and probably should be divided as $\mathrm{V}^{4+}(4 f)$ and $\mathrm{V}^{3+}(2 b)$. In contrast, it can be expected from the stoichiometry that $\mathrm{V}$ is +4 in $\mathrm{Ba}_{3} \mathrm{~V}_{2} \mathrm{~S}_{4} \mathrm{O}_{3}[9,10]$, but the observations correspond to a charge disproportionation: $\mathrm{V}^{3+}$ is found in an octahedral $\left[\mathrm{VS}_{6 / 2}\right]^{3-}$ coordination and $\mathrm{V}^{5+}$ in a $\left[\mathrm{VSO}_{3}\right]^{3-}$ tetrahedron [10], agreeing with the HSAB principle. Similarly, tetrahedrally coordinated $\mathrm{V}^{5+}$ and an intermediate valence of $\mathrm{V}^{26 / 7+}$ in $\left[\mathrm{VS}_{6 / 3}\right]^{2 / 7-}$-octahedra were reported in $\mathrm{Sr}_{6} \mathrm{~V}_{9} \mathrm{~S}_{22} \mathrm{O}_{2}$ but no magnetic moment was observed, agreeing with a lack of true charge ordering [17]. However, in $\mathrm{Ba}_{15} \mathrm{~V}_{12} \mathrm{~S}_{34} \mathrm{O}_{3}$ three oxidation states $\left(\mathrm{V}^{3+}, \mathrm{V}^{4+}, \mathrm{V}^{5+}\right)$ were proven experimentally and a suggested charge ordering was presented (Figure 2), as based on the existence of a short vandyl bond, $(\mathrm{V}=\mathrm{O})^{2+}$, the HSAB principle, and Coulombic repulsion forces [18]. Obviously, the anion superstructure offers several different coordination environments for the transition metal, which seems to be an important prerequisite for the ordering of multiple oxidation states of one element on neighboring sites in a mutual crystal structure. In metal oxides, similar situations were suggested in $\mathrm{La}_{4} \mathrm{Mn}_{5} \mathrm{Si}_{4} \mathrm{O}_{22}$ [19] $\left(\mathrm{Mn}^{2+}, \mathrm{Mn}^{3+}\right.$, and $\left.\mathrm{Mn}^{4+}\right)$ and in $\mathrm{Ba}_{3} \mathrm{Co}_{10} \mathrm{O}_{17}\left(\mathrm{Co}^{2+}, \mathrm{Co}^{3+}\right.$, and $\left.\mathrm{Co}^{4+}\right)$ [20]. However, only the former was supported by spectroscopic data [19].

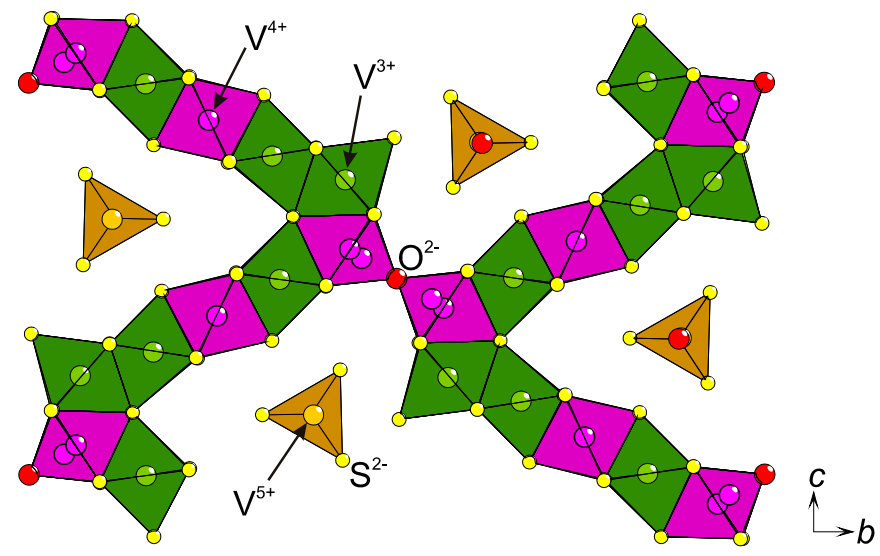

Figure 2. Part of the $\mathrm{V}-\mathrm{S}-\mathrm{O}$ lattice in the crystal structure of $\mathrm{Ba}_{15} \mathrm{~V}_{12} \mathrm{~S}_{34} \mathrm{O}_{3}$. The proposed charge ordering is emphasized with different colors: $\mathrm{V}^{3+}$ (green), $\mathrm{V}^{4+}$ (purple), and $\mathrm{V}^{5+}$ (yellow) [18]. At the $\mathrm{V}-\mathrm{O}-\mathrm{V}$ junction, both half-occupied split-positions of $\mathrm{V}$ are indicated.

These, still rare, crystal structures prove that the lattice energy can surpass the electrochemical potential of redox pairs, which has to be studied further. Having several oxidation states of one element in one compound might induce novel optic and electronic properties.

\subsection{Low Formal Oxidation States of Cations}

A typical feature for the heavier chalcogens is the chemical non-stoichiometry towards reduced oxidation states of involved metals, exemplified by the non-stoichiometric $\mathrm{Fe}_{1+x} \mathrm{Te}$ having an $\alpha-\mathrm{PbO}$ 
type structure but with an additional partly occupied Fe site [21]. This is naturally also a consequence of the more covalent bonding character of $\mathrm{Te}$ - as compared to $\mathrm{O}$, for example-and of the electronic itinerancy. Hence, to reach low formal oxidations states of transition metals, a combination of heavier chalcogenides with lighter ones can be the right strategy. Recently, the layered compound $\mathrm{CsV}_{2} \mathrm{~S}_{2} \mathrm{O}$ was reported with $\mathrm{V}$ having the formally intermediate charge +2.5 [22]. However, metallic properties were observed, meaning that new systems have to be found for the study of the low oxidation states. Still, it is fair to assume that the combination of hard and soft anions (i.e., according to HSAB) might stabilize rare charges of cations.

\subsection{Polar Coordinations}

A cation in a homogeneous anion lattice will bond similarly to its next neighbors, with a predictable coordination number $(\mathrm{CN})$, as estimated from its ionic size relative to the anion size. However, within lattices consisting of two different anions, it is more challenging to make similar predictions. So far, no one has tried to settle any rules for the cations coordination in a heterogeneous anion lattice.

It is well established that the amount of covalency in the bonding nature between two elements is dependent on their differences in electronegativities. By introducing two different anions in the coordination of a common cation, the bonding will obtain irregularities (Figure 3). The bond distance between two specific atoms, e.g., $\mathrm{Zn}$ and $\mathrm{O}$, varies somewhat depending on the other neighboring anions. Examples of this effect can be found in ternary bichalcogenides of actinides or lanthanides, like $\mathrm{Gd}_{2} \mathrm{Se}_{2} \mathrm{O}$ [23] and $\mathrm{Ce}_{2} \mathrm{TeO}_{2}$ [24], but also in $\mathrm{ZrSO}$ [25], and $\mathrm{Ba}_{2} \mathrm{TeO}$ [26]. These four compounds- $\mathrm{Gd}^{3+}, \mathrm{Ce}^{3+}, \mathrm{Zr}^{4+}$, and $\mathrm{Ba}^{2+}-$ have heteroleptic coordinations, and the bonding to either chalcogenide is clearly different from those in a homogeneous anion lattice (see Table 1). More specifically, heteroleptic coordination induces shorter $M-\mathrm{O}(M=$ metal) and longer $M-C h$ $(\mathrm{Ch}=$ chalcogen $)$ distances in comparison to the corresponding bonds in homoleptic coordinations. This is also valid for ions of lighter elements like $\mathrm{Fe}^{2+}$ in the more complex compounds $A E \mathrm{Fe}_{2} \mathrm{Ch}_{2} \mathrm{O}\left(\mathrm{AE}=\mathrm{Ba}^{2+}, \mathrm{Sr}^{2+}, \mathrm{Ch}=\mathrm{S}^{2-}, \mathrm{Se}^{2-}\right)[27-30]$, where $\mathrm{Fe}^{2+}$ has a quasi-tetrahedral $\left[\mathrm{FeS}_{3 / 3} \mathrm{O}_{1 / 2}\right]^{-}$coordination and the $\mathrm{Fe}-\mathrm{S}$ distance is surprisingly large, whereas $\mathrm{Fe}-\mathrm{O}$ is correspondingly short in comparison to bonds in pure sulfides and oxides, respectively [30]. Naturally, this has strong influence on the involved magnetic coupling strengths, local electric polarizations, and crystal fields (see below). Similar situations can be observed in metal-organic complexes but those crystal structures are usually based on finite transition metal entities separated by organic molecules. On the contrary, in superstructures of anions, the lattices are extended and will cause global effects, so far, with unpredictable consequences.
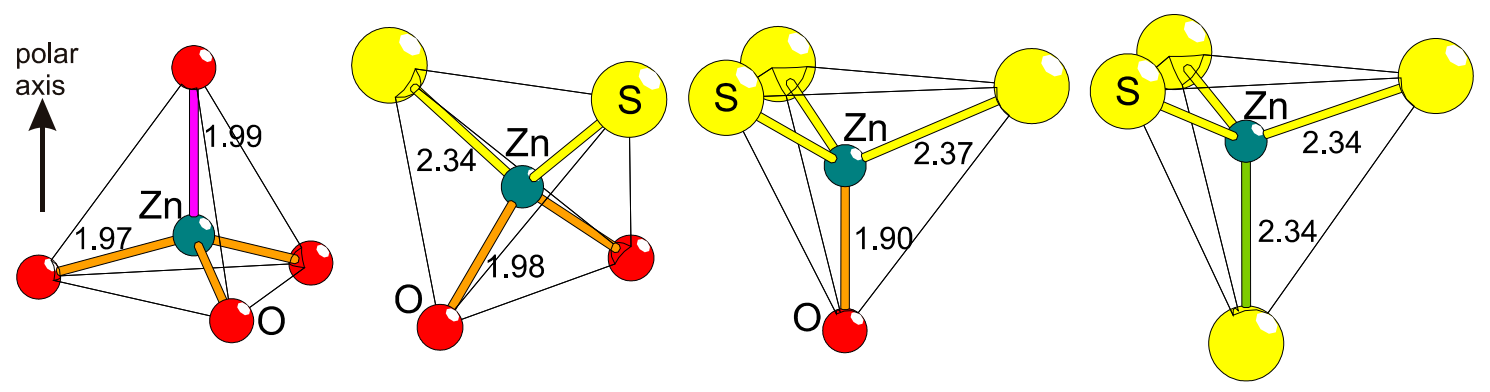

Figure 3. The principle of polar tetrahedral coordination is exhibited, as induced on $\mathrm{Zn}$ by S and O through heteroleptic coordination with comparisons to homoleptic ones. Displayed are, from left to right, the known examples $\mathrm{ZnO}$ [31], BaZnSO [6], CaZnSO [32], and 2H-ZnS [33]. The interatomic distances are differently colored to emphasize their different lengths (in $\AA$ ). 
Table 1. Comparisons of average bond lengths (in $\AA$ ) for cations in homo- or heteroleptic coordination. Average distances are normalized by site multiplicities. The reference materials might contain two cations, but the cation of interest is chosen to have the same oxidation state and similar coordination number $(\mathrm{CN})$ to validate the comparison. Bold fonts in formulas indicate the cations $(\mathbf{M})$ in focus and Ch signifies chalcogens.

\begin{tabular}{|c|c|c|c|c|}
\hline $\mathbf{M}-\mathrm{Ch}-\mathrm{O}$ & $\mathrm{CN}^{1} \times \mathrm{M}-\mathrm{O}$ & $\mathrm{CN}^{1} \times \mathrm{M}-\mathrm{S}$ & $\mathrm{CN}^{1} \times \mathrm{M}-\mathrm{Se}$ & $\mathrm{CN}^{1} \times \mathbf{M}-\mathrm{Te}$ \\
\hline $\mathrm{Gd}_{2} \mathrm{Se}_{2} \mathrm{O}[23]$ & $2 \times 2.30$ & & $5 \times 2.98$ & \\
\hline $\mathrm{Gd}_{2} \mathrm{Ti}_{2} \mathrm{O}_{7}[34], \mathrm{Gd}_{2} \mathrm{Se}_{3}$ & $8 \times 2.46$ & & $7.5 \times 2.98$ & \\
\hline $\mathrm{Ce}_{2} \mathrm{TeO}_{2}[24]$ & $4 \times 2.37$ & & & $4 \times 3.51$ \\
\hline $\mathrm{Ce}_{2} \mathrm{Zr}_{2} \mathrm{O}_{7}[36], \mathrm{Ce}_{8 / 3} \mathrm{Te}_{4}$ [37] & $8 \times 2.47$ & & & $8 \times 3.31$ \\
\hline ZrSO [25] & $3 \times 2.13$ & $4 \times 2.63$ & & \\
\hline $\mathrm{ZrO}_{2}$ [38], $\mathrm{Er}_{2} \mathrm{ZrS}_{5}$ [39] & $8 \times 2.21$ & $7 \times 2.59$ & & \\
\hline $\mathrm{Ba}_{2} \mathrm{TeO}[26]$ & $1 \times 2.45$ & & & $5 \times 3.59$ \\
\hline $\mathrm{BaO}$ [40], $\mathbf{B a}_{2} \mathrm{MnTe}_{3}$ [41] & $6 \times 2.76$ & & & $7 \times 3.54$ \\
\hline
\end{tabular}

${ }^{1}$ Average coordination number.

\subsection{Structural Polarity}

A local polarity, as induced by heterogeneous (heteroleptic) coordination can result in a global polarity, if the crystal structure is described with a non-centrosymmetric space group. For example, $\mathrm{BaGeSe}_{2} \mathrm{O}$ contains $\mathrm{GeSe}_{2} \mathrm{O}_{2}$ tetrahedra, where the highly charged $\mathrm{Ge}^{4+}$ is found far from the tetrahedral center due to the obvious size difference between Se and O [42]; the non-linear optic response from non-centrosymmetric $\mathrm{BaGeSe}_{2} \mathrm{O}\left(\mathrm{P}_{2} 2_{1}{ }_{1} 2_{1}\right)$ is surprisingly large. Another example is CaZnSO $\left(\mathrm{P}_{3} m c\right)$ with strong electric polarity for tetrahedrally coordinated $\mathrm{Zn}^{2+}\left(\left[\mathrm{ZnS}_{3 / 3} \mathrm{O}\right]^{2-}\right.$, Figure 3) [32]; Although the measured sample was polycrystalline, the second harmonic generation (SHG) effect is about 100 times stronger in CaZnSO than in $\alpha-\mathrm{SiO}_{2}$. By replacing the non-magnetic $\mathrm{Zn}^{2+}$ with the $S=2$ entity high-spin $\mathrm{Fe}^{2+}$, the isostructural $\mathrm{CaFeSO}$ was formed [43], where a magneto-electric coupling might result, although only a weak orbital moment is expected for a high-spin $d^{6}$ electronic configuration in tetrahedral coordination. However, according to the first report on this compound, a collinear anti-ferromagnetic long range order in each crystal structure layer was observed, which is further surprising because of the geometrical frustration from the hexagonal symmetry.

An indirect electric polarity is induced by non-magnetic $\left[\mathrm{VSO}_{3}\right]^{3-}$ units on a quasi-1-D magnetic $(S=1)$ system in $\mathrm{Ba}_{3} \mathrm{~V}_{2} \mathrm{~S}_{4} \mathrm{O}_{3}$ (Figure 4): the trigonal packing of columns consisting of face-sharing $\left[\mathrm{VS}_{6 / 3}\right]^{3-}$ octahedra are separated by $\mathrm{Ba}^{2+}$ and polar $\left[\mathrm{VSO}_{3}\right]^{3-}$ tetrahedra that all have a common polar direction $[9,10]$. The first investigations on its physical properties reveal two broad magnetic anomalies without long ranged spin-order, which might indicate thermal excitations of states that are induced by magneto-electric couplings [10].

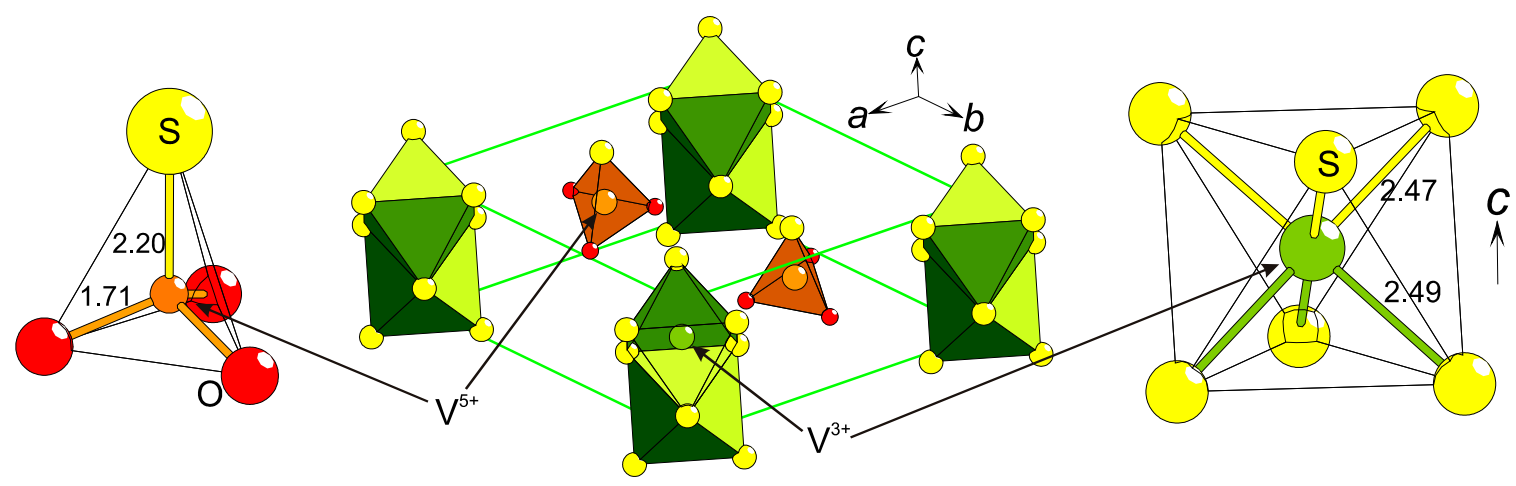

Figure 4. The polar $\left[\mathrm{VSO}_{3}\right]^{3-}$ unit (left) imposes an indirect electric polarization on the quasi-1-D $\left[\mathrm{VS}_{6 / 2}\right]^{3-}$ chain in $\mathrm{Ba}_{3} \mathrm{~V}_{2} \mathrm{~S}_{4} \mathrm{O}_{3}$ (center). This causes a shift of $\mathrm{V}^{3+}$ within the chain (right). All distances are in $\AA$ and $\mathrm{Ba}^{2+}$ ions were left out for simplification. 
A similar 1-D magnetic sublattice is found in $\mathrm{La}_{3} \mathrm{WTMS}_{3} \mathrm{O}_{6}(T M=\mathrm{Cr}, \mathrm{Mn}, \mathrm{Fe}, \mathrm{Co}, \mathrm{Ni})$ [44]. By replacing $\mathrm{Ba}^{2+}$ by $\mathrm{La}^{3+}$ and the polar $\left[\mathrm{VSO}_{3}\right]^{3-}$ unit by the non-polar $\left[\mathrm{WO}_{6}\right]^{6-}$ trigonal prism, the quasi-1-D magnetic lattices can be obtained with $\left(\mathrm{P6}_{3}\right)$ or without $\left(P 6_{3} / \mathrm{m}\right)$ structural polarity. To emphasize this, the compounds can be written as $\mathrm{Ba}_{3}\left[\mathrm{VSO}_{3}\right]\left[\mathrm{TMS}_{6 / 2}\right]$ and $\mathrm{La}_{3}\left[\mathrm{WO}_{6}\right]\left[\mathrm{TMS}_{6 / 2}\right]$, where the $\left[T_{M S} / 2\right]^{3-}$ columns are very similar even with the same +3 oxidation state of $T M$. This offers the unique situation to check the influence of the structural polarity on the material properties (magnetism, conductivity) on basically identical TM sublattices. While this is not necessarily a result of anion ordering, the significant electric polarity in non-centrosymmetric $\mathrm{Ba}_{3}\left[\mathrm{VSO}_{3}\right]\left[\mathrm{TMS}_{6 / 2}\right]$ is assured by the heteroleptically coordinated $\mathrm{V}^{5+}$ (Figure 4).

\subsection{Coordination Configurations and Crystal Field Effects}

The valence electrons of the first row TMs $(\mathrm{Sc}-\mathrm{Zn})$ are strongly affected by the surrounding crystal field, which has consequences for energy differences between possible spin-states. With two different coordinating anions, there are more possibilities to design the crystal field strength and resulting relative energy of the orbitals on the TM. If the energy difference between two spin-states is relatively small, a transition between them can be achieved by means of temperature change and/or magnetic fields change (metamagnetism). The spin-state change is normally accompanied by a change in electrical conductivity, which is highly interesting for fundamental and applied science. For example, the spin-state transition in $\mathrm{Sr}_{2-x} \mathrm{La}_{x} \mathrm{CoO}_{4}$ is related to the metal-insulator transition [45]. On the other hand, the spin-states of transition metals in compound with heterogeneous anionic lattice are far from understood.

As a consequence of (at least) two different coordinating anions, new coordination situations can be expected with novel crystal fields. Especially for the TM ions, it is interesting to explore and to identify new electronic environments that influence the local polarity and the distribution of electrons among the $d$-orbitals. For tetrahedra, $3+1$ and $2+2$ coordinations are possible (Figure 3 ), of which a distorted type of the former is seen for $\mathrm{Fe}^{2+}\left(\mathrm{HS}, d^{6}\right)$ in $A E \mathrm{Fe}_{2} \mathrm{Ch}_{2} \mathrm{O}\left(A E=\mathrm{Ba}^{2+}, \mathrm{Sr}^{2+}\right.$, $\left.\mathrm{Ch}=\mathrm{S}^{2-}, \mathrm{Se}^{2-}\right)$ [38-41] and in CaFeSO [43]. The latter 2+2 coordination is found for $\mathrm{TM}^{2+}$ in BaTMSO $\left(T M=\mathrm{Zn}^{2+}[8], \mathrm{Co}^{2+} \mathrm{HS}, d^{7}\right.$ [46]) and $\mathrm{Fe}^{2+}\left(\mathrm{HS}, d^{6}\right)$ in $\mathrm{CaFeSeO}$ [47]. Cis and trans 2+2 distorted square planar coordinations of two electronically noble-gas-like anions have not been reported in bulk material to date, but should be possible. Numerous different five-fold coordinations are possible, but the two heteroleptic $4+1$ and $3+2$ configurations are most reasonable. A square pyramidal version of $4+1$ is known for $\mathrm{Mn}^{3+}$ (HS, $\left.d^{4}\right)$ in $\mathrm{Sr}_{2} \mathrm{Mn}_{2} \mathrm{SeO}_{4}$ [14]. The $3+2$ coordination has not been reported yet for bichalcogenides, but holds at least the possible cis and trans configurations that result in obviously different crystal fields. Moreover, a hypothetical trigonal bipyramidal trans coordination is likely to occur when the plane is constituted by the relatively smaller anions. The six-fold coordination has even more possibilities, namely $5+1,4+2$, and $3+3$, of which all have several configurational names (Figure 5). So far, $5+1$ has been reported for $\mathrm{Cr}^{3+}\left(d^{3}\right)$ in $\mathrm{LaCrS}_{2} \mathrm{O}$ [48], for $\mathrm{Ti}^{3+}\left(d^{1}\right)$ in $\mathrm{La}_{4} \mathrm{Ti}_{2} \mathrm{Se}_{5} \mathrm{O}_{4}$ [49], and for $\mathrm{Ti}^{4+}\left(d^{0}\right)$ in $\mathrm{La}_{6} \mathrm{Ti}_{3} \mathrm{Se}_{9} \mathrm{O}_{5}$ [49]. A $4+2$ coordination can be either cis, at least known for $\mathrm{Ti}^{4+}\left(d^{0}\right)$ in $\mathrm{Pr}_{6} \mathrm{Ti}_{2} \mathrm{~S}_{7} \mathrm{O}_{6}$ [50], or trans as for $\mathrm{Fe}^{2+}\left(\mathrm{HS}, d^{6}\right)$ in $\mathrm{La}_{2} \mathrm{Fe}_{2} \mathrm{Se}_{2} \mathrm{O}_{3}$ [12]. The facial (fac) and the meridional (mer) $3+3$ coordinations are still very rare and were almost solely reported for metal-organic complexes, where polydental ligands make it possible to control the fac and mer isomerism. However, in extended crystals structure with monoatomic anions, the mer coordination in bichalcogenides only exists for non-magnetic $\mathrm{Ti}^{4+}\left(d^{0}\right)$ in $\mathrm{La}_{6} \mathrm{Ti}_{2} \mathrm{~S}_{7} \mathrm{O}_{6}$ [51]. Higher coordination numbers than six are mainly reported for lanthanides, actinides, and larger main group metals, see for example $\mathrm{Gd}_{2} \mathrm{Se}_{2} \mathrm{O}$ [23], $\mathrm{Ce}_{2} \mathrm{TeO}_{2}$ [24], USeO [52], and BiCuSO [53]. Seven-fold capped trigonal antiprismatic coordinations are known for $\mathrm{Zr}^{4+}\left(d^{0}\right)$ in $\mathrm{ZrSO}$ and $\mathrm{Nb}^{5+}\left(d^{0}\right)$ in $\mathrm{Gd}_{3} \mathrm{NbS}_{3} \mathrm{O}_{4}$. Further seven-fold (or higher) coordination might be possible at least for Mn or for TMs of later periods ( $4 d$ or $5 d$ ). 

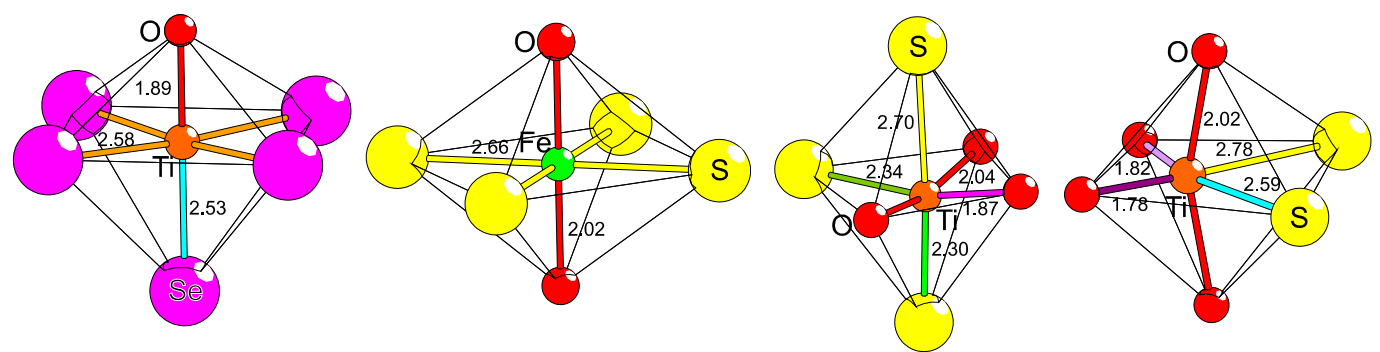

Figure 5. Different heteroleptic octahedral bichalcogenide coordinations of transition metals. From left to right: [ $\left.\mathrm{TiSe}_{4 / 2} \mathrm{Se}_{1 / 1} \mathrm{O}_{1 / 1}\right]^{4-}$ in $\mathrm{La}_{4} \mathrm{Ti}_{2} \mathrm{Se}_{5} \mathrm{O}_{4}$ [49], trans-[ $\left.\mathrm{FeS}_{4 / 4} \mathrm{O}_{2 / 4}\right]^{-}$in $\mathrm{La}_{2} \mathrm{Fe}_{2} \mathrm{Se}_{2} \mathrm{O}_{3}$ [12], mer- $\left[\mathrm{TiS}_{3 / 1} \mathrm{O}_{3 / 2}\right]^{5-}$ in $\mathrm{La}_{6} \mathrm{Ti}_{2} \mathrm{~S}_{8} \mathrm{O}_{5}$ [51], and cis- $\left[\mathrm{TiS}_{1 / 1} \mathrm{~S}_{1 / 2} \mathrm{O}_{2 / 1} \mathrm{O}_{2 / 2}\right]^{5-}$ in $\operatorname{Pr}_{6} \mathrm{Ti}_{2} \mathrm{~S}_{7} \mathrm{O}_{6}$ [50] are shown. Interatomic bonds with the same color have the same bond lengths (in $\AA$ ).

Clearly, the coordination flexibility is at hand, but a spin-state transition (HS-LS) has not been fully proven yet, although it was suggested for $\mathrm{Co}^{3+}\left(d^{6}\right)$ in $\mathrm{La}_{3} \mathrm{WCoS}_{3} \mathrm{O}_{6}$ [44], where Co is trigonal antiprismatically coordinated by $\mathrm{S}^{2-}$ solely.

\subsection{Coordination Disproportionation}

$\mathrm{LaCrS}_{2} \mathrm{O}$ is a quasi-1-D system with zig-zag chains of $\left[\mathrm{CrS}_{3 / 3} \mathrm{~S}_{2 / 2} \mathrm{O}_{1 / 1}\right]^{3-}$ edge-sharing octahedra (Figure 6, left), where $\mathrm{La}^{3+}$ ions separate the chains. By introducing the slightly smaller lanthanide ion $\mathrm{Ce}^{3+}$ instead of $\mathrm{La}^{3+}$, the lattice experiences a so-called "chemical pressure". As a result, the crystal structure of $\mathrm{CeCrS}_{2} \mathrm{O}$ consists of layers (Figure 6, right) built from two different octahedra that are edge- and vertex-sharing and are separated by $\mathrm{Ce}^{3+}$ ions. The structural difference between the two chemically similar systems can be described as a coordination disproportionation: $\mathrm{LaCrS}_{2} \mathrm{O}$ contains only $\left[\mathrm{CrS}_{3 / 3} \mathrm{~S}_{2 / 2} \mathrm{O}_{1 / 1}\right]^{3-}$ entities [48] and $\mathrm{CeCrS}_{2} \mathrm{O}$ contains equal amount of $\left[\mathrm{CrS}_{4 / 2} \mathrm{~S}_{2 / 3}\right]^{7 / 3-}$ and $\left[\mathrm{CrS}_{4 / 3} \mathrm{O}_{2 / 1}\right]^{11 / 3}-$ octahedra in an ordered fashion [54] (Figure 6). As it is clearly not a charge ordering phenomenon, this might be related to coordination order entropy that is rarely taken into consideration. An alternative explanation would be that the $5+1$ coordination in $\mathrm{LaCrS}_{2} \mathrm{O}$ is relatively unstable, as indicated by the fact that the highly symmetrical electron distribution on $\mathrm{Cr}^{3+}$ in an octahedron $\left(3 t_{2 \mathrm{~g} O e_{\mathrm{g}}}\right)$ does not agree with the relatively low symmetry of the $\mathrm{Cr}$-site, i.e., four different bond lengths are found in the structure (Figure 6). Coordination disproportionation is also found in $\mathrm{CeCrSe}_{2} \mathrm{O}$ and even in $\mathrm{LaCrSe}_{2} \mathrm{O}$ [55], leaving $\mathrm{LaCrS}_{2} \mathrm{O}$ as only example, so far, with homogeneous $5+1$ coordination of $\mathrm{Cr}^{3+}$.
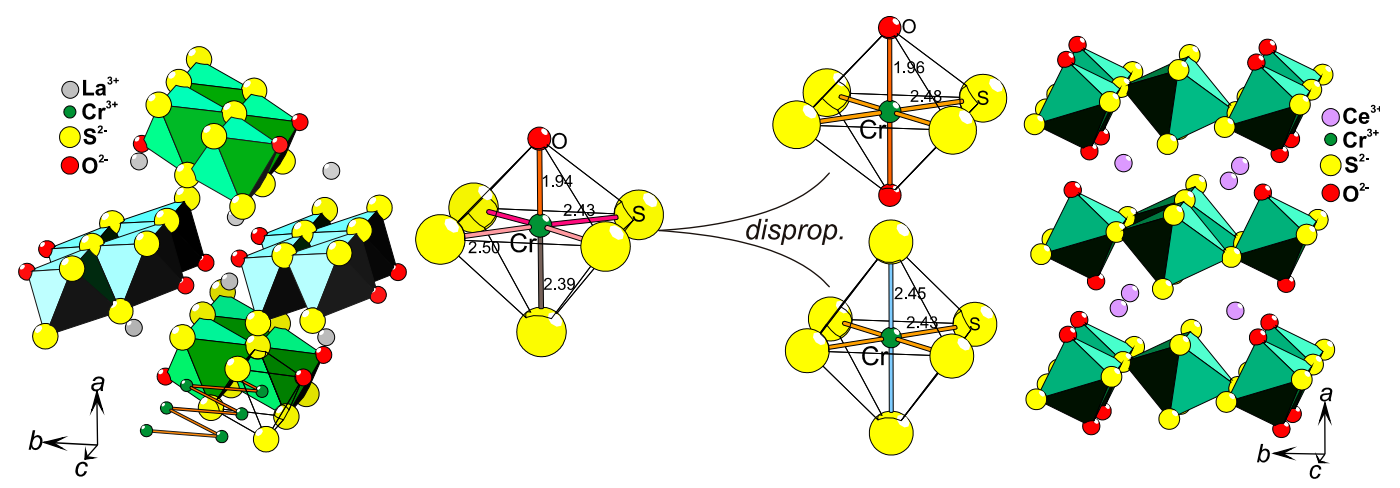

Figure 6. Parts of the $R E C r S_{2} \mathrm{O}(R E=\mathrm{La}, \mathrm{Ce})[48,54]$ crystal structures are displayed (left and right). In $\mathrm{LaCrS}_{2} \mathrm{O}$ (left), the 1-D rows of $\left[\mathrm{CrS}_{3 / 3} \mathrm{~S}_{2 / 2} \mathrm{O}_{1 / 1}\right]^{3-}$ edge-sharing octahedra are high-lighted, while the layers of edge- and vertex-sharing $\left[\mathrm{CrS}_{4 / 3} \mathrm{O}_{2 / 1}\right]^{11 / 3}--\left[\mathrm{CrS}_{4 / 2} \mathrm{~S}_{2 / 3}\right]^{7 / 3}-$ octahedra in $\mathrm{CeCrS}_{2} \mathrm{O}$ are exhibited (right). In the center, the coordination disproportionation is shown as changes in local coordination of $\mathrm{Cr}$, where all distances (in $\AA$ ) are added. 
This type of polymorphism is probably described for the first time here and has to be studied further to understand its origin: The complex anionic lattice might be an ideal starting point for finding further examples of this phenomenon.

\subsection{Magnetic Anisotropy}

On an extended lattice, the magnetic interactions via super-exchange paths will be affected by heteroleptic coordinations of magnetic ions. The $\mathrm{S}-\mathrm{O}$ ordering in $\mathrm{BaCoSO}$ [46] constitutes a new type of parameter causing magnetic anisotropy (Figure 7). The extraordinary bonding situation results in two different super-exchange paths, $\mathrm{Co}-\mathrm{S}-\mathrm{Co}$ and $\mathrm{Co}-\mathrm{O}-\mathrm{Co}$, that run parallel to two orthogonal crystallographic directions, $a$ and $c$, respectively (Figure 7). The magnetic interactions between the $S=3 / 2$ entities $\left(\mathrm{Co}^{2+}\right)$ are dependent on inter-atomic distances, bonding type (hopping integral), and bridges angle $\left(\mathrm{Co}-\mathrm{S}-\mathrm{Co}\left(116^{\circ}\right)\right.$ or $\left.\mathrm{Co}-\mathrm{O}-\mathrm{Co}\left(180^{\circ}\right)\right)$. All of these parameters, being different for the super-exchange via $\mathrm{S}$ or $\mathrm{O}$, cause the magnetic coupling strengths to differ. Hence, the magnetic system BaCoSO is not obviously 2-D, as even the layers are anisotropic and carry features of a 1-D lattice.

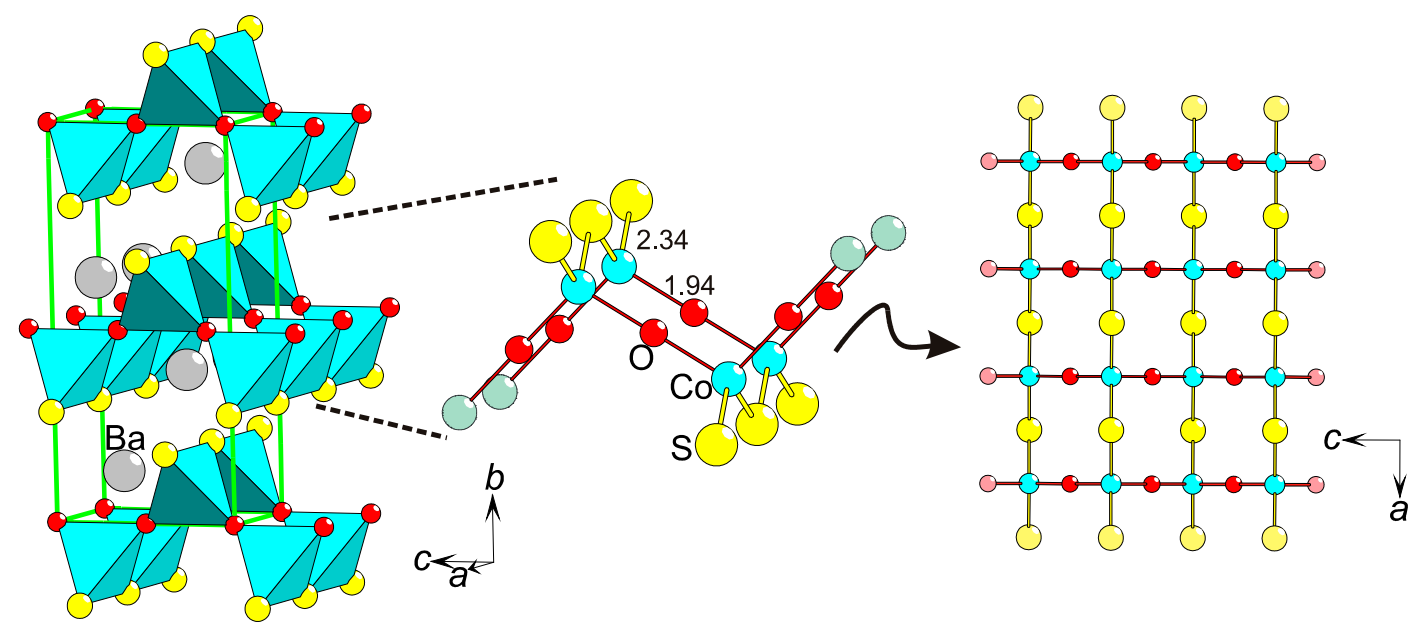

Figure 7. Magnetic anisotropy by chalcogen ordering in BaCoSO [46]. Displayed are: a part of the $\mathrm{BaCoSO}$ structure with unit cell in green (left), the local Co coordination (center), and the Co-S-O layer viewed along the $b$-axis. Interatomic distances are in $\AA$.

Moreover, the low-dimensional surrounding, as formed by different sizes of next-neighbor ions, allows for orbital moments of magnetic ions or for a coupling between spin and structural polarity to evolve (see above).

It is clear that the ordering of anions can be counted as additional parameters for designing magnetic anisotropy.

\subsection{Band-Gap Optimization}

The covalent bond character of heavier anions to cations will decrease the electronic correlation strengths locally and decrease the band-gap globally: $\mathrm{ZnO}$ is a typical electronic insulator, $\mathrm{ZnS}$ and $\mathrm{ZnSe}$ are semiconductors, and $\mathrm{ZnTe}$ is metallic. The electronic properties of hypothetical compositions $\mathrm{Zn}_{2} \mathrm{SO}$ and $\mathrm{Zn}_{2} \mathrm{TeO}$ are, thus, difficult to predict and can be affected by the dimensionality of the anionic lattice. As the band-gap is important for several applicable materials, like in thermoelectrics and for photocatalytic splitting of water, compounds including heavier chalcogenides are receiving more attention lately. $\mathrm{BiCuSeO}$ is a prominent example with exceptional thermoelectric properties [56]. Its band-gap of about $0.8 \mathrm{eV}$ increases proportionally to the $\mathrm{S}$ content in $\mathrm{BaCuSe}_{1-x} \mathrm{~S}_{x} \mathrm{O}$ up to about $1.1 \mathrm{eV}$ [57], proving that this chalcogenide compound can be anion designed in a predictable way. The exceptional thermoelectric properties are naturally also a consequence of the low thermal 
conductivity, which is discussed as related to the 2-D layers of $\mathrm{O}$ and $\mathrm{Se}(\mathrm{S})$. Hence, the anion superstructure improves the applicable properties with its bonding anisotropy.

\section{Further Notes}

Anionic superstructures are only beginning to reveal their potential. In fact, there are several open problems in fundamental and applied sciences that might be solved by introducing the anionic superstructures as extra parameter in the design of related materials. For example, ionic conductors are often suffering from structural deterioration upon using the material, moving the ions; in cases where the moving ion is an anion, these compounds could be improved by introducing two anions, where one is moving and the other is holding the lattice together, perhaps in layers or in columns. On the other hand, if the moving ion is a cation, the anionic lattice can be designed with two ions to reach optimum diffusion paths. An already known example is $\mathrm{Ag}_{3} \mathrm{SI}$ with a combined anionic lattice and extremely high cationic mobility [58].

Even more intricate anionic lattices are known: $\mathrm{Ln}_{3} \mathrm{SOF}_{5}(\mathrm{Ln}=\mathrm{Nd}, \mathrm{Sm}, \mathrm{Gd}-\mathrm{Ho})$ contain three different anions with only little mixing of $\mathrm{F}^{-}$and $\mathrm{O}^{2-}$ [59]. The coordination is naturally more complex and the possibilities for the above mentioned parameters are extended. Heteroleptic coordinations by three anions in ordered layers of $\mathrm{U}_{2} \mathrm{Te}_{2} \mathrm{PO}$ result in two different surroundings for $\mathrm{U}$ : either $\mathrm{UTe}_{5} \mathrm{O}_{4}$ or $\mathrm{UTe}_{5} \mathrm{P}_{4}$ [60]. Although the charge ordering was not stated in that report, the HSAB principle [16] suggests $\mathrm{U}^{5+}$ in former and $\mathrm{U}^{4+}$ in latter.

\section{Final Words}

Several of the above-mentioned phenomena are induced by the ordering of anions and the examples, presented here, only contained the bichalcogenides. Pnictogens in combination with chalcogens are already making the head-lines due to LaFePO [61] and related materials, but in that case Fe is homoleptically coordinated and does not have the same parameters of freedom as the materials in this review. However, the pnictogenide halogenide $\mathrm{ZrNCl}$ [62] does connect to the topic of this review and also exhibits superconductivity upon electronic doping. By combining a chalcogen with complex anions, further possibilities are obvious, and thereof $\mathrm{Bi}_{4}\left(\mathrm{SO}_{4}\right) \mathrm{S}_{2}$ is a prominent example, which is reported to be superconducting [63]. Hence, further systematic investigations of other anion superstructures are needed, which probably will be as rewarding as this preliminary one for the bichalcogenides.

Acknowledgments: The author would like to thank Alexandra Zevalkink for improving the English language in this review.

Conflicts of Interest: The author declares no conflict of interest.

\section{Abbreviations}

The following abbreviations are used in this manuscript:

$\begin{array}{ll}\text { Ch } & \text { Chalcogen } \\ \text { CN } & \text { Coordination Number } \\ \text { D } & \text { Dimensionality } \\ \text { HSAB } & \text { Hard-Soft-Acid-Base } \\ \text { HS } & \text { High Spin } \\ \text { LS } & \text { Low Spin } \\ \text { M } & \text { Metal } \\ r & \text { radius } \\ \text { SHG } & \text { Second Harmonic Generation } \\ \text { TM } & \text { Transition Metal }\end{array}$

\section{References}

1. Hume-Rothery, W.; Powell, H.M. On the Theory of Super-Lattice Structures in Alloys. Z. Kristallogr. 1935, 91, 23-47. [CrossRef] 
2. Shannon, R.D. Revised effective ionic radii and systematic studies of interatomic distances in halides and chalcogenides. Acta Crystallogr. 1976, A32, 751-767. [CrossRef]

3. Zachariasen, W.H. Crystal chemical studies of the $5 f$-series of elements. I. New structure types. Acta Crystallogr. 1948, 1, 265-268. [CrossRef]

4. Zachariasen, W.H. Die Kristallstruktur der $\alpha$-Modifikation von den Sesquioxyden der seltenen Erdmetalle $\left(\mathrm{La}_{2} \mathrm{O}_{3}, \mathrm{Ce}_{2} \mathrm{O}_{3}, \mathrm{Pr}_{2} \mathrm{O}_{3}, \mathrm{Nd}_{2} \mathrm{O}_{3}\right)$. Z. Phys. Chem. 1926, 123, 134-150.

5. Von Schnering, H.G.; Hoppe, R. Die Kristallstruktur des $\mathrm{SrZnO}_{2}$. Z. Anorg. Allg. Chem. 1961, 312, 87-98. [CrossRef]

6. Broadley, S.; Gal, Z.A.; Cora, F.; Smura, C.F.; Clarke, S.J. Vertex-Linked $\mathrm{ZnO}_{2} \mathrm{~S}_{2}$ Tetrahedra in the Oxysulfide BaZnOS: A New Coordination Environment for Zinc in a Condensed Solid. Inorg. Chem. 2005, 44, 9092-9096. [CrossRef] [PubMed]

7. Guittard, M.; Julien-Pouzol, M. Les composes hexagonaux de type $\mathrm{La}_{3} \mathrm{CuSiS}$. Bull. Soc. Chim. Fr. 1970, 1970, 2467-2469.

8. De Saint-Giniez, D.; Laruelle, P.; Flahaut, J. Structure cristalline du sulfure double de cerium et d'aluminium $\mathrm{Ce}_{6} \mathrm{Al}_{3.33} \mathrm{~S}_{14}$. Comptes Rendus 1968, 267, 1029-1032.

9. Calvagna, F.; Zhang, J.-H.; Li, S.-J.; Zheng, C. Synthesis and structural analysis of $\mathrm{Ba}_{3} \mathrm{~V}_{2} \mathrm{O}_{3} \mathrm{~S}_{4}$. Chem. Mater. 2001, 13, 304-307. [CrossRef]

10. Hopkins, E.J.; Prots, Y.; Burkhardt, U.; Watier, Y.; Hu, Z.; Kuo, C.-Y.; Chiang, J.-C.; Pi, T.-W.; Tanaka, A.; Tjeng, L.H.; et al. $\mathrm{Ba}_{3} \mathrm{~V}_{2} \mathrm{~S}_{4} \mathrm{O}_{3}$ : A Mott insulating frustrated quasi-one-dimensional $S=1$ magnet. Chem. Eur. J. 2015, 21, 7938-7943. [CrossRef] [PubMed]

11. Meerschaut, A.; Lafond, A.; Palvadeau, P.; Deudon, C.; Cario, L. Synthesis and crystal structure of two new oxychalcogenides: $\mathrm{Eu}_{5} \mathrm{~V}_{3} \mathrm{~S}_{6} \mathrm{O}_{7}$ and $\mathrm{La}_{10} \mathrm{Se}_{14} \mathrm{O}$. Mater. Res. Bull. 2002, 37, 1895-1905. [CrossRef]

12. Mayer, J.M.; Schneemeyer, L.F.; Siegrist, T.; Waszczak, J.V.; van Dover, R.B. Neue Eisenlanthan-Oxidsulfidund-Oxidselenid-Phasen mit Schichtstruktur: $\mathrm{Fe}_{2} \mathrm{La}_{2} \mathrm{O}_{3} E_{2}(E=\mathrm{S}, \mathrm{Se})$. Angew. Chem. 1992, 104, 1677-1678. [CrossRef]

13. Koyama, E.; Nakai, I.; Nagashima, K. Crystal chemistry of oxide-chalcogenides. II. Synthesis and crystal structure of the first bismuth oxide-sulfide, $\mathrm{Bi}_{2} \mathrm{O}_{2} \mathrm{~S}$. Acta Crystallogr. 1984, B40, 105-109. [CrossRef]

14. Free, D.G.; Herkelrath, S.J.C.; Clarke, S.J. $\mathrm{Sr}_{2} \mathrm{Mn}_{2} \mathrm{O}_{4}$ Se: A New Oxychalcogenide with Antiferromagnetic Chains. Z. Anorg. Allg. Chem. 2012, 638, 2532-2537. [CrossRef]

15. Ijjaali, I.; Bin, D.; Ibers, J.A. Seven new rare-earth transition-metal oxychalcogenides: Syntheses and characterization of $L n_{4} \mathrm{MnOSe}_{6}(\mathrm{Ln}=\mathrm{La}, \mathrm{Ce}, \mathrm{Nd}), \mathrm{Ln}_{4} \mathrm{FeOSe}_{6}(\mathrm{Ln}=\mathrm{La}, \mathrm{Ce}, \mathrm{Sm})$, and $\mathrm{La}_{4} \mathrm{MnOS}_{6}$. J. Solid State Chem. 2005, 178, 1503-1507. [CrossRef]

16. Pearson, R.G. Hard and Soft Acids and Bases; Dowden, Hutchinson \& Ross: Stroudsburg, PA, USA, 1973.

17. Litteer, J.B.; Chen, B.-H.; Fettinger, J.C.; Eichhorn, B.W.; Ju, H.L.; Greene, R.L. Synthesis and magnetic and transport properties of $\mathrm{Sr}_{6} \mathrm{~V}_{9} \mathrm{~S}_{22} \mathrm{O}_{2}$ : " $A M_{2} \mathrm{~S}_{5}$ " phases revisited. Inorg. Chem. 2000, 39, 458-462. [CrossRef] [PubMed]

18. Wong, C.J.; Hopkins, E.J.; Prots, Yu.; Hu, Z.; Kuo, C.J.; Pi, T.W.; Valldor, M. Anionic ordering in $\mathrm{Ba}_{15} \mathrm{~V}_{12} \mathrm{~S}_{34} \mathrm{O}_{3}$, affording three oxidation states of vanadium and a quasi-one-dimensional magnetic lattice. Chem. Mater. 2016, 28, 1621-1624. [CrossRef]

19. Gueho, C.; Giaquinta, D.; Mansot, J.L.; Ebel, T.; Palvadeau, P. Structure and magnetism of $\mathrm{La}_{4} \mathrm{Mn}_{5} \mathrm{Si}_{4} \mathrm{O}_{22}$ and $\mathrm{La}_{4} \mathrm{~V}_{5} \mathrm{Si}_{4} \mathrm{O}_{22}$ : Two new rare-earth transition metal sorosilicates. Chem. Mater. 1995, 7, 486-492. [CrossRef]

20. David, R.; Kabbour, H.; Bordet, P.; Pelloquin, D.; Leynaud, O.; Trentesaux, M.; Mentré, O. Triple Co II, III, IV charge ordering and spin states in modular cobaltites: A systemization through experimental and virtual compounds. J. Mater. Chem. C 2014, 2, 9457-9466. [CrossRef]

21. Haraldsen, H.; Groenvold, F.; Vihovde, J. Faseforholdene i systemet jern-tellur. Tidsskr. Kjem. Bergves. 1944, 4, 96-98.

22. Valldor, M.; Merz, P.; Prots, Y.; Schnelle, W. Bad-Metal-Layered Sulfide Oxide $\mathrm{CsV}_{2} \mathrm{~S}_{2} \mathrm{O}$. Eur. J. Inorg. Chem. 2016, 2016, 23-27. [CrossRef]

23. Tougait, O.; Ibers, J.A. $\mathrm{Gd}_{2} \mathrm{OSe}_{2}$. Acta Crystallogr. 2000, C56, 623-624.

24. Benz, R. $\mathrm{Ce}_{2} \mathrm{O}_{2} \mathrm{Sb}$ and $\mathrm{Ce}_{2} \mathrm{O}_{2}$ Bi crystal structure. Acta Crystallogr. 1971, B27, 853-854. [CrossRef]

25. McCullough, J.D.; Brewer, L.; Bromley, L.A. The crystal structure of zirconium oxysulfide, ZrOS. Acta Crystallogr. 1948, 1, 287-289. [CrossRef] 
26. Besara, T.; Ramirez, D.; Sun, J.; Whalen, J.B.; Tokumoto, T.D.; McGill, S.A.; Singh, D.J.; Siegrist, T. Ba 2 TeO: A new layered oxytelluride. J. Solid State Chem. 2015, 222, 60-65. [CrossRef]

27. Han, F.; Wan, X.; Shen, B.; Wen, H.-H. BaFe ${ }_{2} \mathrm{Se}_{2} \mathrm{O}$ as an iron-based Mott insulator with antiferromagnetic order. Phys. Rev. 2012, B86, 014411. [CrossRef]

28. Lei, H.; Ryu, H.; Ivanovski, V.; Warren, J.B.; Frenkel, A.I.; Cekic, B.; Yin, W.-G.; Petrovic, C. Structure and physical properties of the layered iron oxychalcogenide $\mathrm{BaFe}_{2} \mathrm{Se}_{2} \mathrm{O}$. Phys Rev. 2012, B86, 195133. [CrossRef]

29. Valldor, M.; Adler, P.; Prots, Y.; Burkhardt, U.; Tjeng, L.H. $S=2$ Spin Ladders in the Sulfide Oxide $\mathrm{BaFe}_{2} \mathrm{~S}_{2} \mathrm{O}$. Eur J. Inorg. Chem. 2014, 36, 6150-6155. [CrossRef]

30. Huh, S.; Prots, Y.; Adler, P.; Tjeng, L.H.; Valldor, M. Synthesis and Characterization of Frustrated Spin Ladders $\mathrm{SrFe}_{2} \mathrm{~S}_{2} \mathrm{O}$ and $\mathrm{SrFe}_{2} \mathrm{Se}_{2} \mathrm{O}$. Eur. J. Inorg. Chem. 2015, 18, 2982-2988. [CrossRef]

31. Aminoff, G. Über Lauephotogramme und Struktur von Zinkit. Z. Kristallogr. Cryst. Mater. 1921, 56, 495-505. [CrossRef]

32. Sambrook, T.; Smura, C.F.; Clarke, S.J. Structure and physical properties of the polar oxysulfide CaZnOS. Inorg. Chem. 2007, 46, 2571-2574. [CrossRef] [PubMed]

33. Aminoff, G. Untersuchungen über die Kristallstrukturen von Wurtzit und Rotnickelkies. Z. Kristallogr. Cryst. Mater. 1923, 58, 203-219. [CrossRef]

34. Knop, O.; Brisse, F.; Castelliz, L. Pyrochlores. V. Thermoanalytic, X-ray, neutron, infrared, and dielectric studies of $A_{2} \mathrm{Ti}_{2} \mathrm{O}_{7}$ titanates. Can. J. Chem. 1969, 47, 971-990. [CrossRef]

35. Guittard, M.; Benacerrat, A.; Flahaut, J. Les seleniures $L_{2} \mathrm{Se}_{3}$ et $L_{3} \mathrm{Se}_{4}$ des elements des terres rares. Ann. Chim. 1964, 9, 25-34.

36. Sasaki, T.; Ukyo, Y.; Kuroda, K.; Arai, S.; Muto, S.; Saka, H. Crystal structure of $\mathrm{Ce}_{2} \mathrm{Zr}_{2} \mathrm{O}_{7}$ and $\beta-\left(\mathrm{Ce}_{2} \mathrm{Zr}_{2} \mathrm{O}_{7.5}\right)$. J. Ceram. Soc. Jpn. 2004, 112, 440-444. [CrossRef]

37. Miller, J.F.; Matson, L.K.; Himes, R.C. Studies on the selenides and tellurides of selected rare-earth metals. Proc. Conf. Rare Earth Res. 1962, 1962, 233-248.

38. Böhm, J. Über das Verglimmen einiger Metalloxyde. Z. Anorg. Allg. Chem. 1925, 149, 217-222. [CrossRef]

39. Donohue, P.C.; Jeitschko, W. The preparation of $L n_{2} M X_{5}$ where $L n=$ rare earths, $M=\mathrm{Zr}$ and $\mathrm{Hf}$, and $X=\mathrm{S}$, Se. Mater. Res. Bull. 1974, 9, 1333-1336. [CrossRef]

40. Gerlach, W. Die Gitterstruktur der Erdalkalioxyde. Z. Phys. 1922, 9, 184-192. [CrossRef]

41. Matje, P.; Müller, W.; Schäfer, H. Zur Darstellung und Kristallstruktur von $\mathrm{Ba}_{2} \mathrm{MnTe}_{3}$. Z. Naturforsch. 1977, B32, 835-836.

42. Liu, B.W.; Jiang, X.M.; Wang, G.E.; Zeng, H.Y.; Zhang, M.J.; Li, S.F.; Guo, W.H.; Guo, G.C. Oxochalcogenide $\mathrm{BaGeOSe}_{2}$ : Highly distorted mixed-anion building units leading to a large second-harmonic generation response. Chem. Mater. 2015, 27, 8189-8192. [CrossRef]

43. Jin, S.F.; Huang, Q.; Lin, Z.P.; Li, Z.L.; Wu, X.Z.; Ying, T.P.; Wang, G.; Chen, X.L. Two-dimensional magnetic correlations and partial long-range order in geometrically frustrated $\mathrm{CaOFeS}$ with triangle lattice of Fe ions. Phys. Rev. 2015, B91, 094420. [CrossRef]

44. Bryhan, D.N.; Rakers, R.; Klimaszewski, K.; Patel, N.; Bohac, J.J.; Kremer, R.K.; Mattausch, H.; Zheng, C. $\mathrm{La}_{3} \mathrm{TWS}_{3} \mathrm{O}_{6}(T=\mathrm{Cr}, \mathrm{Mn}, \mathrm{Fe}, \mathrm{Co}, \mathrm{Ni})$ : Quinary Rare Earth Transition-Metal Compounds Showing a Nonmagnetic/Magnetic Transition $(T=\mathrm{Co})$-Synthesis, Structure and Physical Properties. Z. Anorg. Allg. Chem. 2010, 636, 74-78. [CrossRef]

45. Wu, H. Metal-insulator transition in $\mathrm{Sr}_{2-x} \mathrm{La}_{x} \mathrm{CoO}_{4}$ driven by spin-state transition. Phys. Rev. 2012, B86, 075120. [CrossRef]

46. Valldor, M.; Rößler, U.K.; Prots, Yu.; Kuo, C.-Y.; Chiang, J.-C.; Hu, Z.; Kniep, R.; Tjeng, L.H. Synthesis and Characterization of $\mathrm{Ba}[\mathrm{CoSO}]$ : Magnetic Complexity in the Presence of Chalcogen Ordering. Chem. Eur. J. 2015, 21, 10821-10828. [CrossRef] [PubMed]

47. Han, F.; Wang, D.; Malliakas, C.D.; Sturza, M.; Chung, D.Y.; Wan, X.; Kanatzidis, M.G. (CaO)(FeSe): A Layered Wide-Gap Oxychalcogenide Semiconductor. Chem. Mater. 2015, 27, 5695-5701. [CrossRef]

48. Dugué, P.J.; Vovan, T.; Villers, J. Etude Structurale des Oxysulfures de Chrome(III) et de Terres Rares. I. Structure de I'Oxysulfure $\mathrm{LaCrOS}_{2}$. Acta Crystallogr. 1980, B36, 1291-1294. [CrossRef]

49. Tougait, O.; Ibers, J.A. Synthesis and crystal structures of the lanthanum titanium oxyselenides $\mathrm{La}_{4} \mathrm{Ti}_{2} \mathrm{O}_{4} \mathrm{Se}_{5}$ and $\mathrm{La}_{6} \mathrm{Ti}_{3} \mathrm{O}_{5} \mathrm{Se}$. J. Solid State Chem. 2001, 157, 289-295. [CrossRef]

50. Gardberg, A.S.; Ibers, J.A. Crystal structure of hexapraseodymium dititanium septasulfide hexaoxide, $\mathrm{Pr}_{6} \mathrm{Ti}_{2} \mathrm{~S}_{7} \mathrm{O}_{6}$. Z. Kristallogr. 2001, 216, 491-492. [CrossRef] 
51. Cody, J.A.; Ibers, J.A. Synthesis and characterization of the new rare-earth/transition-metal oxysulfides $\mathrm{La}_{6} \mathrm{Ti}_{2} \mathrm{~S}_{8} \mathrm{O}_{5}$ and $\mathrm{La}_{4} \mathrm{Ti}_{3} \mathrm{~S}_{4} \mathrm{O}_{8}$. J. Solid State Chem. 1995, 114, 406-412. [CrossRef]

52. Ferro, R. Über einige Selen-und Tellurverbindungen des Urans. Z. Anorg. Allg. Chem. 1954, 275, 320-326. [CrossRef]

53. Hiramatsu, H.; Yanagi, H.; Kamiya, T.; Ueda, K.; Hirano, M.; Hosono, H. Crystal structures, optoelectronic properties and electronic structures of layered oxychalcogenides $M C \mathrm{CuCh}(M=\mathrm{Bi}, \mathrm{La} ; \mathrm{Ch}=\mathrm{S}, \mathrm{Se}, \mathrm{Te})$ : Effects of electronic configurations of $M^{3+}$ ions. Chem. Mater. 2008, 20, 326-334. [CrossRef]

54. Dugué, P.J.; Vovan, T.; Villers, J. Etude Structurale des Oxysulfures de Chrome(III) et de Terres Rares. II. Structure de I'Oxysulfure $\mathrm{CeCrOS}_{2}$. Acta Crystallogr. 1980, B36, 1294-1297. [CrossRef]

55. Van, T.V.; Huy Ng, D. Synthese et structure cristalld'une nouvelle famille d' oxyselenures de chrome III et de lanthanides legers, de formule generale $\mathrm{RCrSe}_{2} \mathrm{O}(R=\mathrm{La}, \mathrm{Ce})$. Comptes Rendus 1981, 293, 933-936.

56. Zhao, L.-D.; He, J.; Berardan, D.; Lin, Y.; Li, J.-F.; Nanc, C.-W.; Dragoe, N. BiCuSeO oxyselenides: New promising thermoelectric materials. Energy Environ. Sci. 2014, 7, 2900-2924. [CrossRef]

57. Berardan, D.; Li, J.; Amzallag, E.; Mitra, S.; Sui, J.; Cai, W.; Dragoe, N. Structure and Transport Properties of the BiCuSeO-BiCuSO Solid Solution. Materials 2015, 8, 1043-1058. [CrossRef]

58. Reuter, B.; Hardel, K. Über die Hochtemperaturmodifikation von Silbersulfidjodid. Naturwiss 1961, 48, 161-162. [CrossRef]

59. Grossholz, H.; Janka, O.; Schleid, T. Oxide fluoride sulfides of the lanthanoids with the formula $\mathrm{M}_{3} \mathrm{OF}_{5} \mathrm{~S}(\mathrm{M}=\mathrm{Nd}, \mathrm{Sm}, \mathrm{Gd}-\mathrm{Ho})$. Z. Naturforsch. 2011, B66, 213-220. [CrossRef]

60. Stolze, K.; Isaeva, A.; Schwarz, U.; Doert, T. UPTe, ThPTe and $\mathrm{U}_{2} \mathrm{PTe} \mathrm{T}_{2} \mathrm{O}$ : Actinide pnictide chalcogenides with diphosphide anions. Eur. J. Inorg. Chem. 2015, 2015, 778-785. [CrossRef]

61. Kamihara, Y.; Hiramatsu, H.; Hirano, M.; Kawamura, R.; Yanagi, H.; Kamiya, T.; Hosono, H. Iron-Based Layered Superconductor: LaOFeP. J. Am. Chem. Soc. 2006, 128, 10012-10013. [CrossRef] [PubMed]

62. Shamoto, S.; Kato, T.; Ono, Y.; Miyazaki, Y.; Ohoyama, K.; Ohashi, M.; Yamaguchi, Y.; Kajitani, T. Structures of $\beta$-( $\mathrm{ZrNCl})$ and superconducting $\mathrm{Li}_{0.16} \mathrm{ZrNCl}$ : Double honeycomb lattice superconductor. Physica C 1998, 306, 7-14. [CrossRef]

63. Singh, S.K.; Kumar, A.; Gahtori, B.; Shruti, K.; Sharma, G.; Patnaik, S.; Awana, V.P.S. Bulk superconductivity in bismuth oxysulfide $\mathrm{Bi}_{4} \mathrm{O}_{4} \mathrm{~S}_{3}$. J. Am. Chem. Soc. 2012, 134, 16504-16507. [CrossRef] [PubMed]

(C) 2016 by the author; licensee MDPI, Basel, Switzerland. This article is an open access article distributed under the terms and conditions of the Creative Commons Attribution (CC-BY) license (http://creativecommons.org/licenses/by/4.0/). 